\title{
Standardization of stage wise water requirement in drip irrigated Kinnow mandarin orchards under sub-tropical conditions
}

\author{
GURTEG SINGH ${ }^{1 *}$, HARINDER SINGH RATTANPAL ${ }^{1}$, MONIKA GUPTA ${ }^{1}$ and \\ GURUPKAR SINGH SIDHU ${ }^{2}$
}

\author{
${ }^{1}$ Department of Fruit Science, ${ }^{2}$ School of Agricultural Biotechnology, \\ Punjab Agricultural University, Ludhiana 141004, Punjab \\ *Corresponding Author: gurteg-hort@pau.edu
}

\begin{abstract}
An experiment on drip irrigation scheduling based on pan evaporation replenishment was conducted in Kinnow orchard at Punjab Agricultural University, Ludhiana during 2010-2018. Year was divided into six stages (stage 1 to stage $\mathrm{VI}$ ) including two months in each stage. First treatment included irrigation scheduling with 30 and $40 \% \mathrm{ER}$, treatment two with 40 and $60 \% \mathrm{ER}$, treatment three with 60 and $80 \% \mathrm{ER}$, alternatively during stages I to VI. However, fourth and fifth treatments had irrigation with $80 \% \mathrm{ER}$ and $30 \% \mathrm{ER}$, respectively, in all the stages. Maximum daily open pan evaporation $(9.15 \mathrm{~mm})$ was recorded in May and minimum $(1.19 \mathrm{~mm})$ was recorded in January. The water requirement varied from

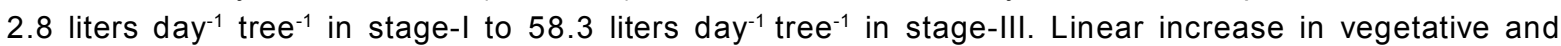
reproductive growth was observed with increase in irrigation water. Polynomial relationship studies indicated the increase in water quantity applied to Kinnow with increase in temperature subject to the prevailing relative humidity. Similarly, volumes of water applied increased with increased mean evaporation. The study concluded that drip irrigation scheduling with 60 to $80 \%$ ER alternatively, starting from January to December save significant amount of water, without affecting yield and quality of Kinnow under subtropical conditions.
\end{abstract}

Key words: Drip irrigation, evaporation, Kinnow and replenishment

Kinnow mandarin is an important commercially grown citrus crop in Punjab. It occupies an area of 53.0 thousand hectares and the annual production is 1.24 million metric tons (Anonymous, 2019). High quality mandarins are produced in Punjab due to cooler nights during winter at the time of maturity. However, Kinnow being an evergreen perennial fruit tree, irrigation water is a key input for higher yield and quality production. Water management usually involves maintenance of high-water status through proper irrigation scheduling. Higher water use efficiency in citrus is very important due to diminishing water resources with prevailing wheat-paddy rotation in Punjab state.

Water saving techniques and strategies based on periodic estimation of soil water balance and special water exchange distribution processes (Provenzano et al., 2013), may lead to crop sustainability in citrus. In India, mandarin orchards are generally irrigated through drip irrigation system. However, evaporation-based irrigation scheduling is more efficient system of water saving. It has been reported in pomegranate (Punica granatum $\mathrm{L}$.) that water requirement by the surface irrigation methods estimated on crop evapotransipiration is even more than water requirement by drip irrigation (Gorantiwar et al., 2011).

The identification of critical stages of water requirement is an important task to make decisions concerning irrigation planning in citrus (Dazhi et al., 2018). Different irrigation approaches like soil moisture dimensions, evapotranspiration (ET) and plant water stress based can be followed depending on the type of stress evidence (Pardossi and Incrocci, 2011). Different agro-meteorological conditions are reported to affect the physiological processes and hence, lower the productivity of different crops (Adak et al., 2012; Kaur et al., 2020).

It has been documented that water requirement at various stages of trees varied from 651 to $997 \mathrm{~mm}$ per year depending upon the prevailing climatic conditions of the region (Ghadekar et al., 1989). Irrigation scheduling at less than 80 per cent of evaporation replenishment (ER) during the all plant growth developmental stages affected the yield and fruit quality in Nagpur mandarin (Shirgure et al., 2014). The saturated area of soil surface should be reduced to 50 to 60 per cent to diminish soil evaporation and to curtail tree transpiration under full grown tree (García-Tejera et al., 
2017). Incomplete root zone drying can be economically beneficial in area of extreme drought to sustain tree growth and yield in citrus (Kusakabe et al., 2016). In recent years, several research reports documented the advantages of optimum irrigation water supply at various flowering and fruit developmental phases in different citrus crops (PérezPérez et al., 2008; Gasque et. al., 2010; García-Tejero et al., 2010).

Growth responses of young 'Nagpur' mandarin plants showed significantly higher annual increase in vegetative parameters with drip irrigation at $80 \%$ of alternate day cumulative pan evaporation (Panigrahi et al., 2012). Panigrahi et al. (2014) advocated that irrigation at 50\% crop evapotranspiration (ETc) during early fruit development stages could save considerable amount of water in 'Kinnow' mandarin without significant reduction in fruit yield. Kinnow plant is highly responsive to water stress at bud sprouting, flowering, fruit set and fruit developmental stages during January-February and March-April under north-India conditions (Hassan and Sirohi, 2006). However, lack of information about the quantity of water required force Kinnow grower to adopt faulty irrigation scheduling which ultimately affects yield and fruit quality.

This experiment was planned with a hypothesis that early fruit development phases from stage II and III during March-April and May-June respectively, coincides with summer months and later stages during winter months may have different water requirement. Furthermore, efficient irrigation management can save substantial water without effecting the yield and quality of produce. Little information is available on plant responses to water stress conditions during developmental phases in Kinnow mandarin under North-Indian conditions. As one of the most important indicators of yield and water deficit conditions is the tree evidently, a new irrigation scheduling in different growth phases of Kinnow may also benefit farmers.

In view of above discussion, an effort was made to study drip system based on pan evaporation-based irrigation scheduling at various plant growth phases and their effect on fruit yield and quality of Kinnow mandarin under subtropical conditions.

\section{MATERIALAND METHODS}

The research was conducted in New Research Farm, Punjab Agricultural, Ludhiana (Latitude, 30 $33^{\circ}$ ' $41^{\prime \prime} \mathrm{N}$ and Longitude, $75^{\circ} 48^{\prime} 26^{\prime \prime}$ E) during 2008 to 2018. 'Kinnow' mandarins budded on rough lemon (Citrus jambhiri Lush) rootstock were used in the study. Trees were planted with 6 $\times 3 \mathrm{~m}$ spacing in October, 2010. The environment of experimental location is categorized as sub-tropical, with annual rainfall of about $630 \mathrm{~mm}$ and out of which $90 \%$ was received during rainy season (July to September). The weekly mean temperature and, mean precipitation and mean relative humidity from 2004 to 2013 and 2014 to 2017 period are given in Fig. 1 and 2, respectively. All the recommended practices except irrigation for Kinnow cultivation were given as per PAU recommendations.

The agro-meteorological data recorded from PAU, Ludhiana observatory were used for applying open pan evaporation based irrigation on the basis of pan evaporation replenishment in various periods of tree progression and fruit growth. Year is divided into six different stages i.e. Stage-I (Jan.-Feb.), Stage-II (Mar.-Apr.), Stage-III (MayJun.), Stage-IV (Jul.-Aug.), Stage-V (Sept.-Oct.) and StageVI (Nov.-Dec.). The treatments were irrigation schedule with $30 \%$ and $40 \%$ ER alternatively from stage-I to stage-IV $\left(\mathrm{T}_{1}\right)$, $40 \%$ and $60 \%$ ER alternatively from stage-I to stage-VI $\left(\mathrm{T}_{2}\right)$, $60 \%$ and $80 \%$ ER alternatively from stage-I to stage-IV $\left(\mathrm{T}_{3}\right)$, $80 \%$ ER for all stages $\left(\mathrm{T}_{4}\right), 30 \%$ ER for all stages $\left(\mathrm{T}_{5}\right)$. Each treatment included five trees and treatments were replicated thrice. Water quantity was determined according to average weekly open pan evaporation (Hasan and Sirohi, 2006).

$$
\mathrm{Etc}=\mathrm{K}_{\mathrm{p}} \times \mathrm{K}_{\mathrm{C}} \times \mathrm{E}_{\mathrm{P}}
$$

Where, Etc (mm); Kp-pan coefficient (0.8), Kc-cropcoefficient (0.80), Ep-2-days cumulative pan evaporation (mm).

The quantity of water applied was calculated by formula (Germana et al., 1992):

$$
\mathrm{V}_{\mathrm{id}}=(\mathrm{D} 2 / 4) \times(\mathrm{ETc} \text { “ Re }) / \mathrm{Ei}
$$

where, $\mathrm{V}_{\mathrm{id}}$-irrigation volume applied (litre tree"1), Dmean tree canopy spread diameter $(\mathrm{m}), \mathrm{R}_{\mathrm{e}}$-effective rainfall depth $(\mathrm{mm})$, and $\mathrm{E}_{\mathrm{i}}$ - irrigation efficiency of drip system $(90 \%) . R_{e}$ was calculated as a sum of soil water content enrichment in root zone $(\mathrm{mm})$ due to rainfall and $\operatorname{Etc}(\mathrm{mm})$ for the rainfall day (Dastane 1978).

To find out the binomial relationships between different parameters, data of weekly mean temperature and mean evaporation were regressed with quantity of water applied to Kinnow with different treatments. Tree canopy volume was calculated by the equation: volume $=0.524 \mathrm{x}$ height $(\mathrm{m}) \times$ (average tree spread diameter $)^{2}$. Physical and chemical characteristics were determined by taking 20 fruits 
Table 1: Average monthly water quantity applied in different irrigation treatments during various stages in years $20015-2018$

\begin{tabular}{|c|c|c|c|c|c|c|c|c|c|c|c|c|}
\hline \multirow[t]{3}{*}{ Treatment } & \multicolumn{12}{|c|}{ Average monthly total water applied (liters/day/tree) } \\
\hline & \multicolumn{2}{|c|}{ Stage 1} & \multicolumn{2}{|c|}{ Stage 2} & \multicolumn{2}{|c|}{ Stage 3} & \multicolumn{2}{|c|}{ Stage 4} & \multicolumn{2}{|c|}{ Stage 5} & \multicolumn{2}{|c|}{ Stage 6} \\
\hline & Jan. & Feb. & March & April & May & June & July & Aug. & Sept. & Oct. & Nov. & Dec. \\
\hline $\mathrm{T}_{1}$ & 2.8 & 5.3 & 11.6 & 23.2 & 21.9 & 20.8 & $\mathrm{R}$ & $\mathrm{R}$ & 10.2 & 8.2 & 7.1 & 4.7 \\
\hline $\mathrm{T}_{2}$ & 3.8 & 7.1 & 17.4 & 34.8 & 29.1 & 27.7 & $\mathrm{R}$ & $\mathrm{R}$ & 13.6 & 10.9 & 10.6 & 7.0 \\
\hline $\mathrm{T}_{3}$ & 5.7 & 10.6 & 23.3 & 46.4 & 43.7 & 41.5 & $\mathrm{R}$ & $\mathrm{R}$ & 20.5 & 16.4 & 14.1 & 9.3 \\
\hline $\mathrm{T}_{4}$ & 7.6 & 14.1 & 23.3 & 46.4 & 58.3 & 55.3 & $\mathrm{R}$ & $\mathrm{R}$ & 27.3 & 21.9 & 14.1 & 9.3 \\
\hline$\underline{\mathrm{T}_{5}}$ & 2.8 & 5.3 & 8.7 & 17.4 & 21.9 & 20.8 & $\mathrm{R}$ & $\mathrm{R}$ & 10.2 & 8.2 & 5.3 & 3.5 \\
\hline
\end{tabular}

$\mathrm{T}_{1}$ : irrigation schedule with $30 \%$ and $40 \%$ ER alternatively from stage 1 to stage $6, \mathrm{~T}_{2}: 40 \%$ and $60 \%$ ER alternatively from stage 1 to stage $6, \mathrm{~T}_{3}: 60 \%$ and $80 \%$ ER alternatively from stage 1 to stage $6, \mathrm{~T}_{4}: 80 \%$ ER for all stages and $\mathrm{T}_{5}: 30 \%$ for all stages, R-Rainfall

in each replication. Total soluble solids (TSS) were calculated with Erma-hand refractometer $\left(0-32^{\circ} \mathrm{Brix}\right)$ and fruit acidity $(\%)$ in fresh fruits was determined by the method as suggested byAOAC (1995).

The data were analyzed as per standard procedure of Randomized Block Design (RBD). Critical difference at 5\% level of probability was calculated to compare different treatments. Analysis of variance was exhibited for various quantitative traits using SAS (Statistical analysis system) 9.3 version software.

\section{RESULTS AND DISCUSSION}

\section{Irrigation scheduling and water requirement}

The daily maximum open pan evaporation $(9.15 \mathrm{~mm})$ was recorded in May and minimum was recorded in January $(1.19 \mathrm{~mm})$. It had been observed that water requirement increased from stage-I to stage-II due to rise in temperature and longer daylengths. Water requirement of bearing Kinnow orchard varied from stage-I to stage-VI. There was a linear increase in water requirement up to stage 3 and thereafter a decrease in water requirement was noticed due to onset of monsoon and winter season from stage-IV to VI, respectively (Table 1). The water requirement among treatments varied from 2.8 liters day $^{-1}$ tree $^{-1}$ in stage-I to 58.3 litres day $^{-1}$ tree $^{-}$ ${ }^{1}$ in stage-III. In treatment one, where the irrigation scheduling was applied with 30 to $40 \%$ ER alternatively from stage-I to stage-VI, water requirement varied from 2.8 liters day $^{-1}$ tree $^{-}$ 1 in stage-I to 23.2 liters day ${ }^{-1}$ tree $^{-1}$. However, water requirement varied from 3.8 liters day $^{-1}$ tree $^{-1}$ in stage-I to 34.8 liters day $^{-1}$ tree $^{-1}$ in stage-II where the irrigation was applied with 40 to $60 \%$ ER. For treatment three, water requirement varied from 5.7 (stage-I) to 46.4 liters day $^{-1}$ tree- $^{-}$
${ }^{1}$ (stage-II). With 80\% ER irrigation scheduling in treatment four, water requirement varied from 7.6 (stage-I) to 58.3 liters day ${ }^{-1}$ tree $^{-1}$ (stage-III). However, in treatment five, where irrigation was given at $30 \% \mathrm{ER}$, lowest water requirement (2.8 to 21.9 liters day ${ }^{-1}$ tree $\left.^{-1}\right)$ was recorded at all the stages (Table 1 ).

The results indicated that water requirement increased from stage-I to stage-III and thereafter it reduced. The agrometeorological data recorded during 2004 to 2013 and 2014-2017 (Fig. 1 and 2) indicated that higher temperature and low humidity level during stage III (week 22 to 25) increased open pan evaporation rate and the water requirement of trees increased drastically. However, thereafter onset of rains coupled with low temperature resulted in decreased water requirement of the trees. In another study, significantly higher annual increase in tree height, scion girth, and canopy volume with drip irrigation at $80 \%$ of alternate day cumulative pan evaporation had been reported in Nagpur mandarin (Panigrahi et al. 2012).

\section{Relationship between temperature and volume of water applied}

The polynomial relationship between temperature and volume of water applied was assessed through graphical and equation representation between two variables. Figure 3 illustrates the relationship between weekly mean temperature and volume of water applied to Kinnow mandarin plants at different ER values. The polynomial equation of second order described the relationship between the two variables (Eq. 1-5). It is clear that water requirement increase with increase in temperature (Fig. 3) subject to the prevailing relative humidity (Fig. 2)

These results showed that volume of water required 


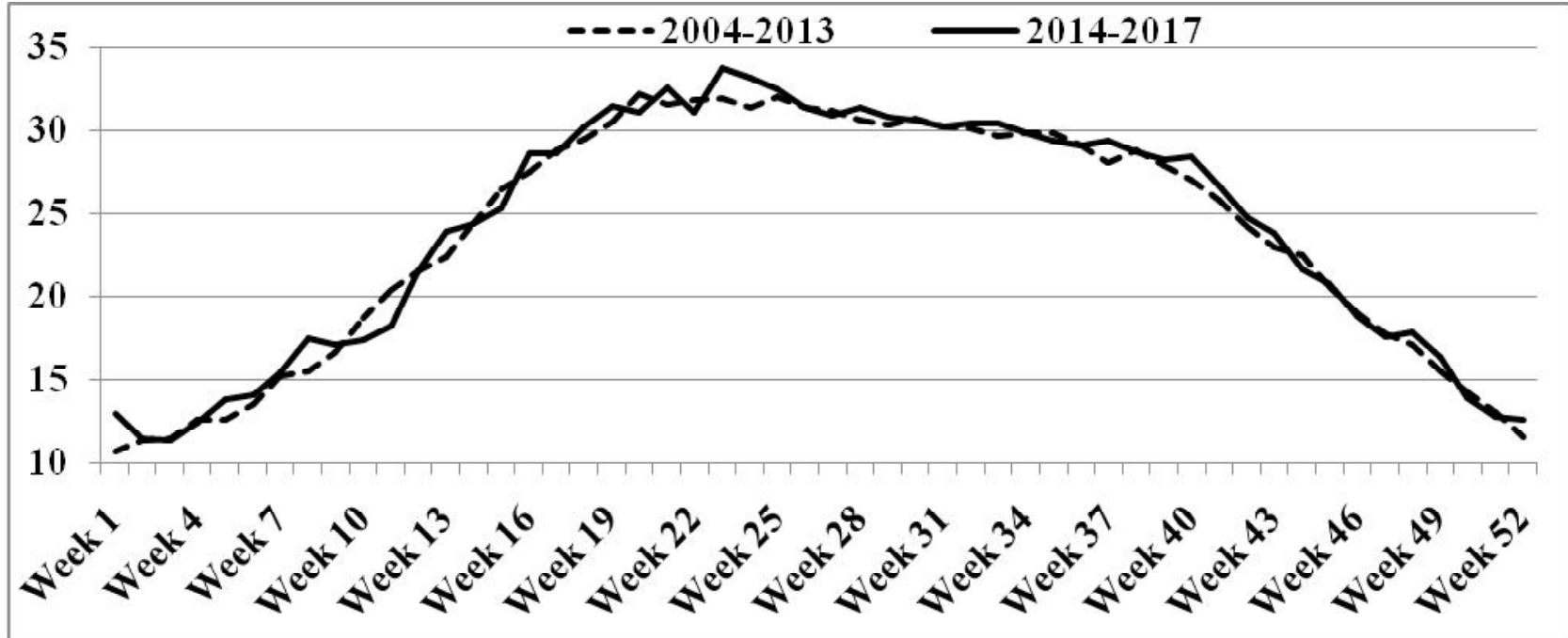

Fig. 1: Weekly mean temperature $\left({ }^{\circ} \mathrm{C}\right)$ of experimental site during 2004-2013 and 2014-2017

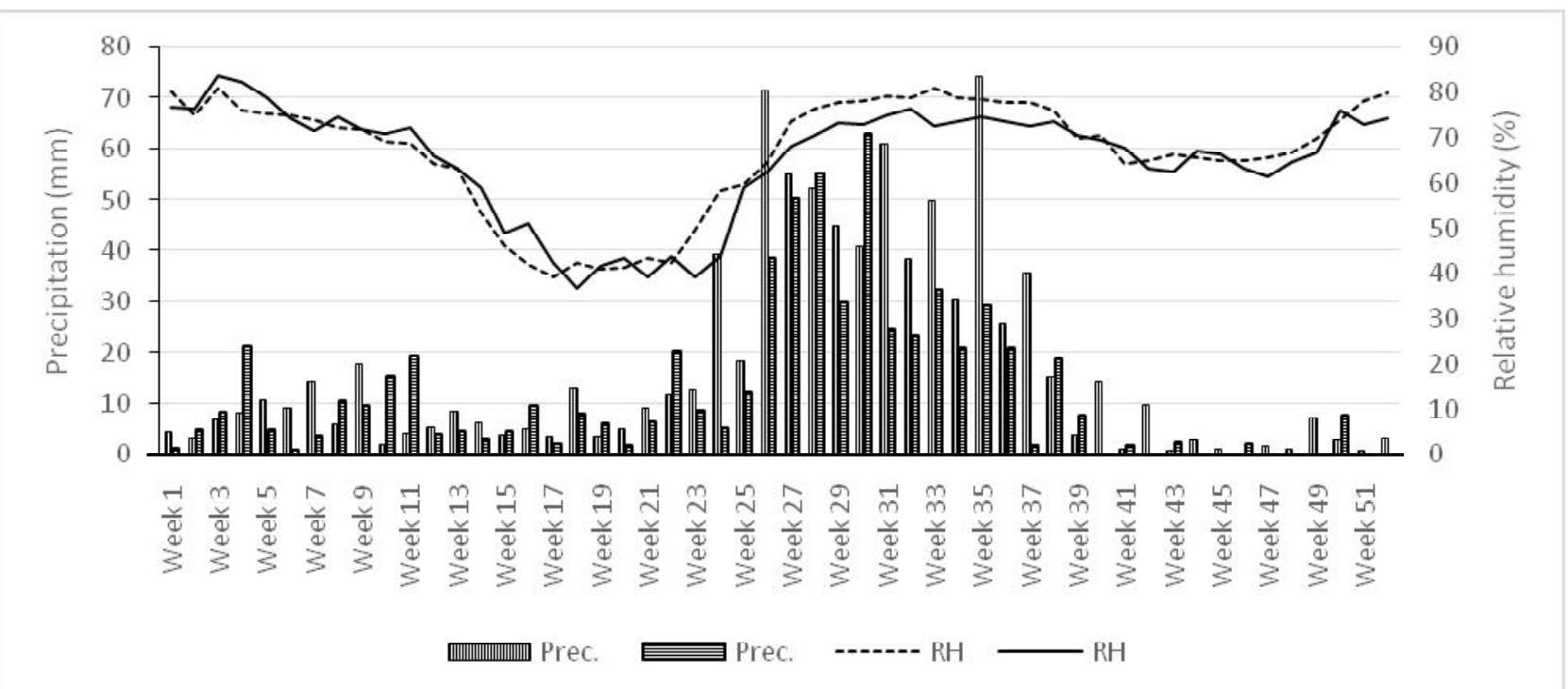

Fig. 2: Weekly precipitation (mm) and weekly relative humidity(\%)) of experimental site during 2004-2013 and 2014-2017

for drip irrigation to Kinnow mandarin shoots to its maximum for the period between March-April.

$\mathrm{y}=-0.031 \mathrm{x}^{2}+1.71 \mathrm{x}-13.49, \mathrm{R}^{2}=0.350(\mathrm{~T} 1,30-40 \% \mathrm{ER})$

$y=-0.080 x^{2}+3.77 x-32.72, R^{2}=0.386(T 2,40-60 \% E R)$

$\mathrm{y}=-0.138 \mathrm{x}^{2}+6.37 \mathrm{x}-56.1, \mathrm{R}^{2}=0.408(\mathrm{~T} 3,60-80 \% \mathrm{ER})$

$y=-0.158 x^{2}+7.50 x-64.9, R^{2}=0.381(T 4,80 \% E R)$

$y=-0.084 x^{2}+4.53 x-35.62, R^{2}=0.348(T 5,30 \% E R)$

Where, $y=$ volume of irrigation water applied and $\mathrm{x}=$ weekly mean temperature.

\section{Relationship between weekly mean evaporation and the volume of water applied}

These results suggest that volume of irrigation water applied to Kinnow mandarins increased with increased weekly mean evaporation (Fig. 4). The highest volume of irrigation water applied at different ER range was observed for the months with highest mean weekly temperature leading highest evaporation from soil. The polynomial relationships describing the relationship between increased volumes of irrigation water applied with increased mean evaporation are described in Eq. 6-10.

$$
\begin{aligned}
& y=0.004 x^{2}-0.278 x+9.31, R^{2}=0.989(T 1,30-40 \% E R) . \\
& y=0.075 x^{2}-0.581 x+16.8, R^{2}=0.990(T 2,40-60 \% E R) . \\
& y=0.009 x^{2}-0.046 x+18.4, R^{2}=0.990(T 3,60-80 \% E R) . \\
& y=0.002 x^{2}+0.126 x+6.81, R^{2}=0.988(T 4,80 \% E R) \ldots \ldots . . . \\
& y=0.001 x^{2}+0.044 x+2.61, R^{2}=0.988(T 5,30 \% E R) \ldots \ldots . . .
\end{aligned}
$$


Table 2: Effect of different treatments on tree height, canopy volume and scion girth of Kinnow mandarin under sub-tropical conditions

\begin{tabular}{|c|c|c|c|c|c|c|c|c|c|c|c|c|}
\hline Treatment & \multicolumn{4}{|c|}{ Tree height (m) } & \multicolumn{4}{|c|}{ Canopy volume $\left(\mathrm{m}^{3}\right)$} & \multicolumn{4}{|c|}{ Scion girth $(\mathrm{cm})$} \\
\hline $\mathrm{T} 1$ & $3.51^{\mathrm{cd}}$ & $3.75^{\mathrm{c}}$ & $3.98^{\mathrm{bc}}$ & $3.75^{\mathrm{c}}$ & $15.50^{\mathrm{cd}}$ & $19.36^{\mathrm{cd}}$ & $22.27^{\mathrm{cd}}$ & $19.04^{\mathrm{cd}}$ & $28.11^{\mathrm{d}}$ & $30.21^{\mathrm{abcd}}$ & $33.20^{\mathrm{abcd}}$ & $30.51^{\mathrm{abcd}}$ \\
\hline $\mathrm{T} 2$ & $3.68^{\mathrm{bc}}$ & $3.68^{\mathrm{cd}}$ & $3.82^{\text {cde }}$ & $3.73^{\mathrm{cd}}$ & $15.59^{\mathrm{c}}$ & $19.85^{\mathrm{c}}$ & $23.05^{\mathrm{c}}$ & $19.50^{c}$ & $29.12^{\mathrm{abc}}$ & $31.24^{\mathrm{abc}}$ & $33.90^{\mathrm{abc}}$ & $31.42^{\mathrm{abc}}$ \\
\hline $\mathrm{T} 3$ & $3.80^{\mathrm{ab}}$ & $3.95^{\mathrm{ab}}$ & $4.26^{\mathrm{a}}$ & $4.00^{\mathrm{a}}$ & $20.36^{\mathrm{ab}}$ & $24.62^{\mathrm{ab}}$ & $30.21^{\mathrm{a}}$ & $25.06^{\mathrm{ab}}$ & $29.25^{\mathrm{ab}}$ & $31.95^{\mathrm{ab}}$ & $35.20^{\mathrm{a}}$ & $32.13^{\mathrm{a}}$ \\
\hline $\mathrm{T} 4$ & $3.84^{\mathrm{a}}$ & $3.96^{\mathrm{a}}$ & $4.13^{\mathrm{ab}}$ & $3.98^{\mathrm{ab}}$ & $23.02^{\mathrm{a}}$ & $26.86^{\mathrm{a}}$ & $29.03^{\mathrm{ab}}$ & $26.30^{\mathrm{a}}$ & $29.48^{\mathrm{a}}$ & $31.98^{\mathrm{a}}$ & $34.60^{\mathrm{ab}}$ & $32.02^{\mathrm{ab}}$ \\
\hline $\mathrm{SE}$ (mean) & 0.08 & 0.07 & 0.08 & 0.07 & 1.79 & 1.92 & 1.87 & 1.84 & 0.36 & 0.53 & 0.62 & 0.50 \\
\hline $\mathrm{CD}(\mathrm{P}=0.05)$ & 0.18 & 0.16 & 0.18 & 0.16 & 4.01 & 4.30 & 4.17 & 4.10 & 0.81 & 1.20 & 1.39 & 1.12 \\
\hline
\end{tabular}

$\mathrm{T}_{1}$ : irrigation schedule with $30 \%$ and $40 \%$ ER alternatively from stage 1 to stage $6, \mathrm{~T}_{2}: 40 \%$ and $60 \%$ ER alternatively from stage 1 to stage $6, \mathrm{~T}_{3}: 60 \%$ and $80 \%$ ER alternatively from stage 1 to stage $6, \mathrm{~T}_{4}: 80 \%$ ER for all stages and $\mathrm{T}_{5}: 30 \%$ for all stages

Table 3: Effect of different treatments on fruit weight, fruit number per tree and tree yield of Kinnow mandarin under sub-tropical

\begin{tabular}{|c|c|c|c|c|c|c|c|c|c|c|c|c|}
\hline \multirow[t]{2}{*}{ Treatment } & \multicolumn{4}{|c|}{ Fruit weight(g) } & \multicolumn{4}{|c|}{ Fruit numberper tree } & \multicolumn{4}{|c|}{ Fruityield (kg/tree) } \\
\hline & $2015-16$ & $2016-17$ & $2017-18$ & Mean & $2015-16$ & $2016-17$ & $2017-18$ & Mean & $2015-16$ & $2016-17$ & $2017-18$ & Mean \\
\hline $\mathrm{T} 2$ & $150.9^{c}$ & $157.0^{\mathrm{abc}}$ & $160.5^{\mathrm{c}}$ & $156.1^{\mathrm{c}}$ & $350.8^{c}$ & $394.0^{\mathrm{abc}}$ & $488.0^{\mathrm{bc}}$ & $410.9^{\mathrm{ca}}$ & $52.9^{\mathrm{bc}}$ & $59.9^{\mathrm{bc}}$ & $78.3^{\mathrm{cd}}$ & $63.7^{\mathrm{c}}$ \\
\hline T5 & $138.4^{\text {cde }}$ & $141.5^{\text {de }}$ & $159.6^{\mathrm{cd}}$ & $146.5^{\text {cde }}$ & $284.9^{\mathrm{e}}$ & $325.0^{\mathrm{e}}$ & $497.0^{\mathrm{bc}}$ & $369.0^{\text {de }}$ & $39.4^{\text {de }}$ & $46.0^{\mathrm{c}}$ & $79.3^{c}$ & $54.9^{\text {cde }}$ \\
\hline $\mathrm{SE}$ (mean) & 5.86 & 4.68 & 3.74 & 4.54 & 23.0 & 18.3 & 7.0 & 15.3 & 5.54 & 4.39 & 3.01 & 4.17 \\
\hline $\mathrm{CD}(\mathrm{P}=0.05)$ & 13.11 & 10.45 & 8.37 & 10.16 & 51.4 & 41.0 & 15.7 & 34.1 & 12.39 & 9.82 & 6.73 & 9.33 \\
\hline
\end{tabular}

Table 4: Effect of different treatments on TSS, acidity and TSS/acidity of Kinnow mandarin under sub-tropical conditions

\begin{tabular}{|c|c|c|c|c|c|c|c|c|c|c|c|c|}
\hline Treatment & \multicolumn{4}{|c|}{$\operatorname{TSS}\left(\right.$ Brix $\left.^{\circ}\right)$} & \multicolumn{4}{|c|}{ Acidity (\%) } & \multicolumn{4}{|c|}{ TSS/Acidity } \\
\hline $\mathrm{T} 1$ & $9.41^{\mathrm{cd}}$ & $9.80^{\mathrm{bc}}$ & $9.60^{\mathrm{bc}}$ & $9.60^{\text {bed }}$ & $0.82^{\mathrm{ab}}$ & $0.81^{\mathrm{a}}$ & $0.81^{\mathrm{ab}}$ & $0.81^{\mathrm{a}}$ & $11.48^{\text {cde }}$ & $12.10^{\mathrm{bcd}}$ & $11.85^{\mathrm{bc}}$ & $11.81^{\mathrm{bcd}}$ \\
\hline $\mathrm{T} 2$ & $9.58^{c}$ & $9.40^{\mathrm{d}}$ & $9.20^{\mathrm{d}}$ & $9.39^{\text {bcde }}$ & $0.83^{\mathrm{a}}$ & $0.78^{\mathrm{ab}}$ & $0.78^{\mathrm{bc}}$ & $0.80^{\mathrm{ab}}$ & $11.54^{\mathrm{cd}}$ & $12.05^{\text {bcde }}$ & $11.79^{\text {bcd }}$ & $11.80^{\text {bcde }}$ \\
\hline $\mathrm{T} 3$ & $9.88^{\mathrm{ab}}$ & $10.2^{\mathrm{a}}$ & $10.0^{\mathrm{a}}$ & $10.03^{\mathrm{a}}$ & $0.76^{\mathrm{cd}}$ & $0.69^{d}$ & $0.73^{\text {de }}$ & $0.73^{\mathrm{cd}}$ & $13.00^{\mathrm{ab}}$ & $14.78^{\mathrm{a}}$ & $13.70^{\mathrm{a}}$ & $13.83^{\mathrm{a}}$ \\
\hline $\mathrm{T} 5$ & $9.32^{\text {cde }}$ & $10.10^{\mathrm{ab}}$ & $9.60^{\mathrm{bc}}$ & $9.67^{\mathrm{bc}}$ & $0.78^{\mathrm{bc}}$ & $0.81^{\mathrm{a}}$ & $0.84^{\mathrm{a}}$ & $0.81^{\mathrm{a}}$ & $11.95^{\mathrm{c}}$ & $12.47^{\mathrm{bc}}$ & $11.43^{\text {bcde }}$ & $11.95^{\mathrm{bc}}$ \\
\hline $\mathrm{SE}$ (mean) & 0.12 & 0.17 & 0.13 & 0.10 & 0.02 & 0.02 & 0.02 & 0.02 & 0.48 & 0.50 & 0.42 & 0.42 \\
\hline $\mathrm{CD}(\mathrm{P}=0.05)$ & 0.27 & 0.38 & 0.30 & 0.23 & 0.05 & 0.05 & NS & 0.04 & 1.07 & 1.13 & 0.94 & 0.94 \\
\hline
\end{tabular}

Where, $\mathrm{y}=$ volume of irrigation water applied and $\mathrm{x}=$ weekly mean evaporation.

\section{Tree growth parameters}

The data with respect to tree growth parameters were recorded from fully grown trees during 2016 to 2018 is presented in Table 2 . The maximum average tree height (4.0 $\mathrm{m})$ and average scion girth $(32.13 \mathrm{~mm})$ were recorded in treatment three, where irrigation scheduling was done based on 60 and $89 \%$ ER alternatively from stage-I to stage-VI. These values of tree height and scion girth were at par with treatment four and significantly higher than all other 


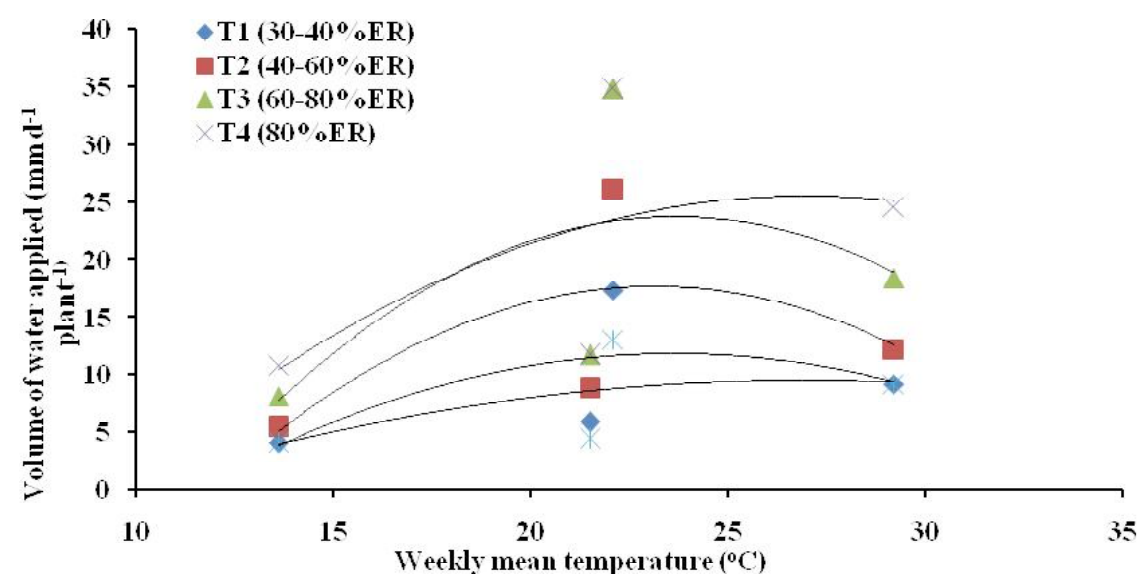

Fig. 3: Relationship between weekly mean temperature $\left({ }^{\circ} \mathrm{C}\right)$ and the volume of irrigation water applied (litre day ${ }^{-1}$ tree $^{-1}$ ) at different ER value ranges for scheduling drip irrigation to Kinnow mandarin.

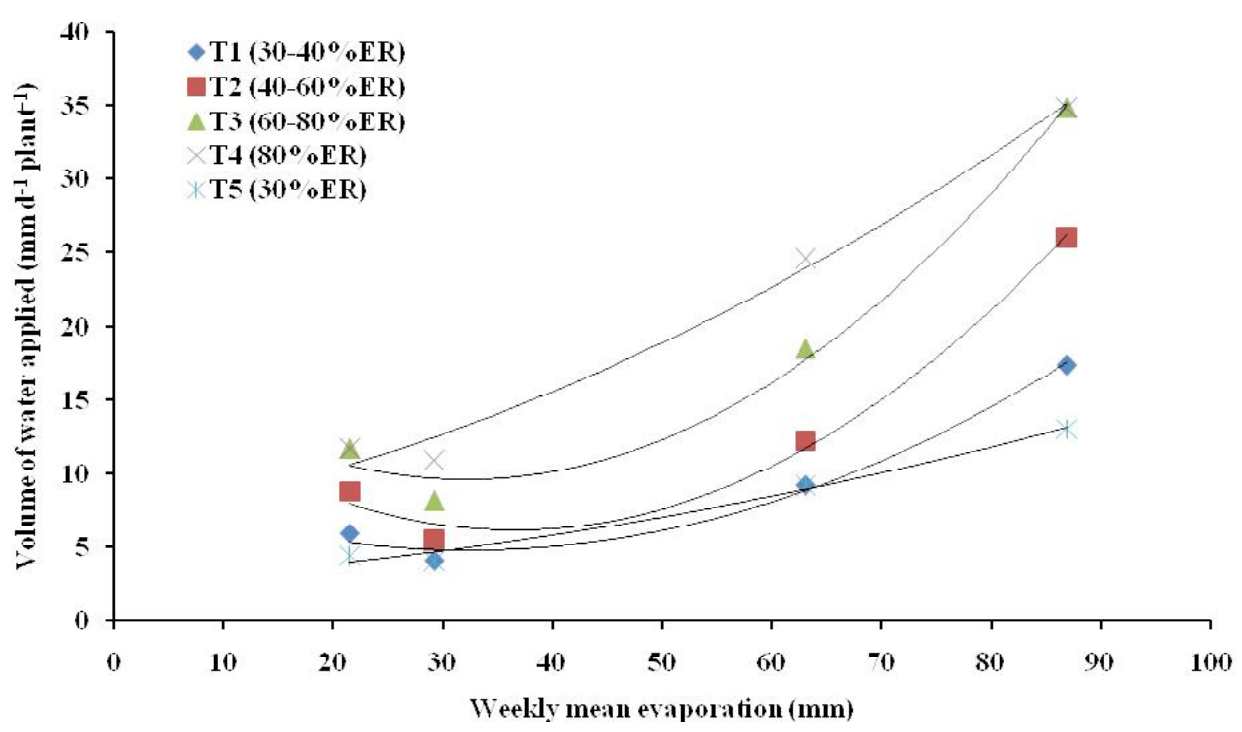

Fig. 4: Relationship between weekly mean evaporation $(\mathrm{mm})$ and the volume of irrigation water applied (litre tree $\left.{ }^{-1}\right)$ at different ER range for scheduling drip irrigation to Kinnow mandarin.

treatments. The significant growth in terms of canopy volume of Kinnow mandarin was observed from 13.23 to $23.02 \mathrm{~m}^{3}$, 16.16 to $26.86 \mathrm{~m}^{3}$ and 21.12 to $30.21 \mathrm{~m}^{3}$ during the year 2015-16, 2016-17 and 2017-18, respectively (Table 2). The highest average canopy volume $\left(26.30 \mathrm{~m}^{3}\right)$ was recorded in treatment four where higher amount of water was applied with $80 \%$ ER scheduling. It was statistically at par with canopy volume of $25.06 \mathrm{~m}^{3}$ in treatment three where 60 and $80 \%$ ER was applied.

The results indicated linear relationship in amount of water applied and tree development parameters. This may be due to better uptake of nutrients by the tree with higher soil moisture which ultimately favours vegetative growth of the tree. Furthermore, high photosynthetic and metabolic accomplishments of fully irrigated trees under favorable soil conditions lead to higher vegetative growth. The results were also supported by Shirgure et al., 2014 who reported higher vegetative growth with higher irrigation in Nagpur mandarin and acid lime trees under central tropical conditions, respectively.

\section{Fruit yield and other attributes}

Drip irrigation scheduling based on open pan evaporation replenishment significantly affected fruit yield and quality in Kinnow mandarin during all the years under report (Table 3, 4). The fruit weight recorded variation from 138.4 to $168.7 \mathrm{~g}, 141.5$ to $169 \mathrm{~g}$ and 156.5 to $174.8 \mathrm{~g}$ during the year 2015-16, 2016-17 and 2017-18, respectively. However, higher fruit weight (169.4 g) was recorded in 
treatment three (60\% and $80 \%$ ER) which was at par with treatment four $(166.5 \mathrm{~g})$ and significantly higher than all other treatments. Significantly higher fruits number per tree (448.6) was recorded in treatment four where the irrigation was scheduled with $80 \% \mathrm{ER}$ and it was at par with treatment three (448 fruits tree ${ }^{-1}$ ) (Table 3 ). The fruit yield varied from 39.4 to $68.3 \mathrm{~kg}$ tre $\mathrm{e}^{-1}, 46.0$ to $70.1 \mathrm{~kg}$ tre $\mathrm{e}^{-1}$ and 75.4 to 90.7 $\mathrm{kg}$ tree ${ }^{-1}$ during the year 2015-16, 2016-17 and 2017-18, respectively. Maximum average yield $\left(76.1 \mathrm{~kg}\right.$ tree $\left.^{-1}\right)$ was recorded in treatment four which were at par with treatment three (74.9 $\left.\mathrm{kg} \mathrm{tree}^{-1}\right)$ (Table 3$)$. Significantly higherTSS and acid ratio (13.83) was recorded in treatment three and it was at par with treatment four (13.19) and significantly higher that all other treatments. The reason behind high fruit TSS and acidity in third treatment is the increased alteration of acids into soluble sugars in dried up juice sacs that is necessary to keep up the osmotic potential of fruit cells under deficit water conditions (Huag et al., 2000).

The results showed that there was a linear increase in vegetative as well as reproductive growth with increase in irrigation water which ultimately resulted in higher tree volume with higher fruit yield and quality. However, no significant difference was noticed in terms of fruit weight and yield if there was increase of water in treatment three ( 60 to $80 \mathrm{ER} \%$ alternatively) to $\mathrm{T}_{4}(80 \% \mathrm{ER})$. The investigation showed that maximum water use efficiency in term of fruit quality and yield could be obtained by irrigating Kinnow orchard at 60 to $80 \%$ ER alternatively from stage-I to stageVI under sub-tropical conditions.

Our results are reinforced by Shirgure et al. (2014) who reported that irrigation scheduling based on evaporation replenishment less than $80 \%$ in all the stages of plant growth affected the yield and fruit quality in Nagpur Mandarin. Furthermore, our results were fully supported by the findings which indicated that deficit irrigation during fruit growth period resulted in $20 \%$ water saving without significant reduction in yield and fruit quality in mandarins (Ballester et al., 2011). Our results were further supported by findings that irrigation at $50 \%$ crop ETc during initial fruit growth period could save significant amount of water in 'Kinnow' mandarin without significant reduction in fruit yield (Panigrahi et al., 2014). Root zone water stress conditions suppressed vegetative growth of plant without affecting much the photosynthetic rate. Hence, more photynthates partitioned from leaves to reproductive growth under deficit irrigation conditions. Similar studies on Kinnow mandarin orchards demonstrated that partial root drying up to 50 per cent improved irrigation water productivity in sandy loam soils (Panigrahi et al., 2013). Similarly, in Navalina' sweet orange (C. sinensis Osbeck), deficit irrigation with 40 to $60 \%$ reduction in irrigation water at initial fruit expansion stage did not affect fruit yield and quality (Gasque et al., 2010). The reduction of fruit yield and quality in Kinnow mandarin with $30 \%$ ER in our study was supported by findings that water stress during flowering and fruit set profoundly decreased fruit yield in sweet oranges (PérezPérez et al., 2008). High evaporation from soil surface during the dry summer season coupled with high temperature and low relative humidity resulted in poor yield and quality in mango cv. Dashehari. (Adak et al., 2017). Our results indicated that adequate water amount (60-80\% ER) of water are especially important during all flowering, fruit set and spring development stages for getting higher yield and quality fruits in Kinnow under Punjab conditions.

\section{CONCLUSION}

The highest volume of irrigation water applied at different ER range was observed for the months with highest mean weekly temperature and evaporation from the soil. Wide variation in vegetative and yield attributes was inferred at different phonological stages during 2015 to 2018 fruiting seasons. However, highest productivity $\left(76.1 \mathrm{~kg} \mathrm{tree}^{-1}\right)$ was recorded in treatment four which were at par with treatment three $\left(74.9 \mathrm{~kg}_{\text {tree }}{ }^{-1}\right)$ with less water applied. Significantly higher fruit TSS and acid ratio (13.83) was recorded in treatment three. So, the study concluded that drip irrigation scheduling with 60 to $80 \mathrm{ER} \%$ alternatively during six growth stages could save substantial water without negotiating with fruit yield and quality in Kinnow orchard under sub-tropical conditions.

\section{ACKNOWLEDGEMENTS}

We are highly thankful to the Project Coordinator, All India Coordinated Research Project on Fruits and ICAR, for providing funds for this research trial.

\section{REFERENCES}

Adak T., Kumar K. and Singh V. K. (2017). Assessment of thermal heat requirement, radiation energy, water use efficiency, and yield of mango cv. Dashehari using fertigation method. J. Agrometeorol., 19 (1): 44-50.

Adak, T., Kumar, G., Narjary B. and Chakravarty, N.V.K. (2012). Micrometeorological dynamics within mustard (Brassica juncea) crop canopy under semi-arid conditions of northern India. J. Agrometeorol., 14(1): 45-49. 
Anonymous. (2019). Anonymous, Package of practices for cultivation of fruits, Punjab Agricultural University, Ludhiana, Punjab, India.

AOAC. (1995). Official methods of analysis of 16th edition. Association of Analytical Chemists, Washington, D.C.

Ballester, C., Castel J., Intrigliolo, D. S. and Castel, J.R. (2011). Response of Clementina de Nules citrus trees to summer deficit irrigation, yield components and fruit composition. Agric. Water Manage. 98:1027-1032.

Dastane, N.G. (1978). Effective rainfall in irrigated agriculture. FAOIrrigation and Drainage Paper25, FAO, Rome, Italy.

Dazhi, L., Harrie-Jan, H.F., Xujun, H., Miguel, A. J., Fernando, M.A. and Harry, V. (2018). Evaluation of an operational real-time irrigation scheduling scheme for drip irrigated citrus fields in Picassent, Agric. Water Manage. 208:465-77.

García-Tejera, O., López-Bernal, A., Orgaz, F., Testi, L. and Villalobos, F.J. (2017). Analyzing the combined effect of wetted area and irrigation volume on olive tree transpiration using a SPAC model with a multicompartment soil solution. Irrig. Sci., 1:1-15.

García-Tejero, I., Romero-Vicente, R., Jiménez-Bocanegra, J.A., Martínez-García, G., Durán-Zuazo, V.H. and MurielFernández, J.L. (2010). Response of citrus trees to deficit irrigation during different phenological periods in relation to yield, fruit quality, and water productivity. Agric. Water Manage., 97: 689-699.

Gasque, M., Granero, B., Turégano, J.V. and González-Altozano, P. (2010). Regulated deficit irrigation effects on yield, fruit quality and vegetative growth of 'Navelina'citrus trees. Spanish J. Agric. Res. 2: 40-51.

Germanà, C., Intrigliolo, F. and Coniglione, L. (1992). Experiences with drip irrigation inorange trees. In: Proceedings of the VII International Citrus Congress of the Inter-national Society of Citriculture. 8-13 March, 1992, Acireale (Catania), Italy, pp.661-664.

Ghadekar, S.R., Dixit, S.V. andPatil, V.P.(1989). Climatological water requirement of the citrus under Nagpur agroclimatic conditions. P.K.V. Research J., 13(2): 143-148.

Gorantiwar, S.D., Meshram, D.T. and Mittal, H.K. (2011). Water requirement of pomegranate (Punica granatum $\mathrm{L}$.) for Ahmednagar district of Maharashtra State, India. $J$. Agrometerol., 13 (2): 123-127.
Hasan, M. and Sirohi, N.P.S. (2006). Irrigation and fertigation scheduling for peach and citrus crops. J. Agric. Eng., 43 (4): $43-46$.

Huag, X., Huag, H.B. and Gao, F. (2000). The growth potential generated in citrus fruits under water stress and its relevant mechanisms. Sci. Hortic. 83: 227-240.

Kaur, S., Gill, M.S., Gill, P.P.S. and Singh, N. (2020). Effect of plant bio-regulators on photosynthesis, growth and yield efficiency of pear trained on Y-trellis system. $J$. Agrometeorol., 22 (2): 232-237.

Kusakabe, A., Contreras-Barragana, B.A., Simpsona, C.R., Encisoc, J.M., Nelsona, S.D. and Melgar, J.C. (2016). Application of partial rootzone drying to improve irrigation wateruse efficiency in grapefruit trees. Agric. Water Manage., 178: 66-75.

Panigrahi, P., Sharma, R.K., Parihar, S.S., Hasan, M. and Rana, D.S. (2013). Economic analysis of drip-irrigated Kinnow mandarin orchard under deficit irrigation and partial root zone drying. Irrig. Drain., 62: 67-73.

Panigrahi, P., Sharmab, R.K., Hasanc, M. and Parihar, S.S. (2014). Deficit irrigation scheduling and yield prediction of 'Kinnow' mandarin (Citrus reticulata Blanco) in a semiarid region. Agric. Water Manage., 140: 48-60.

Panigrahi, P., Srivastava, A.K., Huchche, A.D. and Singh, S. (2012). Plant nutrition in response to drip versus basin irrigation in young 'Nagpur' mandarin on inceptisol. $J$. Pl. Nutrit. 35:215-224.

Pardossi, A. and Incrocci, L. (2011). Traditional and new approaches to irrigation scheduling in vegetable crops. Hort. Technol., 21: 309-313.

Pérez-Pérez, J., Romero, P., Navarro, J. and Botía, P. (2008). Response of sweet orange cv 'Lane late' to deficit irrigation in two rootstocks II: flowering, fruit growth, yield and fruit quality. Irrig. Sci., 26:519-529.

Provenzano, G., Tarquis, A.M. and Rodriguez-Sinobas,L. (2013). Soil and irrigation sustainability practices. Agric. Water Manage., 120:1-4.

Shirgure, P.S., Srivastava, A.K. and Huchche, A.D. (2014). Water requirements in growth stages and effects of deficit irrigation on fruit productivity of drip irrigated Nagpur mandarin (Citrus reticulata). Ind. J. Agril. Sci., 84 (3): 317-322. 